Report No. ER-B-95-06
U.S. Department of Jnergy

Office of Inspector General
Release Date:

August 3, 1995

Report on

Audit of Work Force

Restructuring at the

Oak Ridge Operations

Office

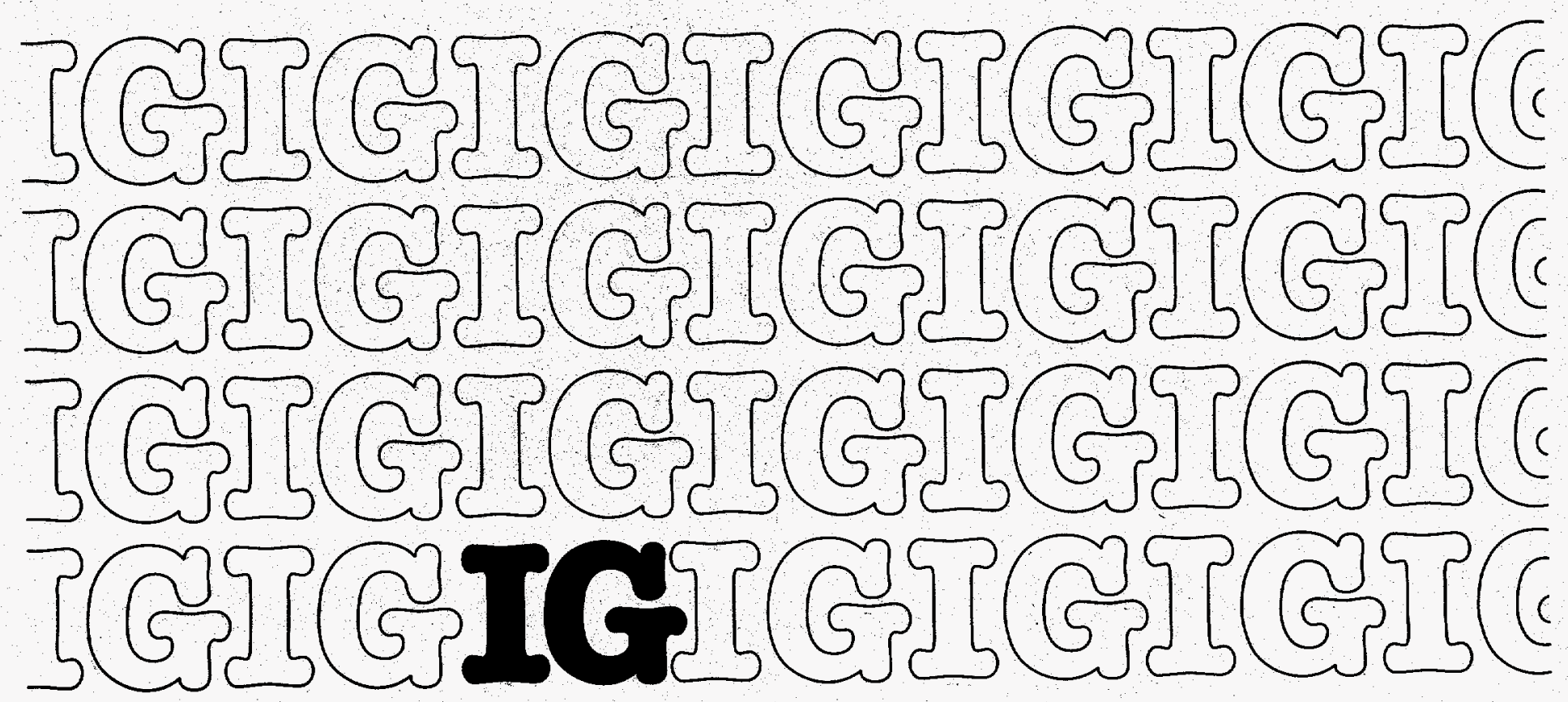


The Office of Inspector General wants to make the distribution of its reports as customer friendly and cost effective as possible. Therefore, this report will be available electronically through the Internet five to seven days after publication at the following alternative addresses:

Department of Energy Headquarters Gopher gopher.hr.doe.gov

Department of Energy Headquarters Anonymous FTP vml .hqadmin.doe.gov

Department of Energy Human Resources and Administration Home Page http://www.hr.doe.gov/refshelf.html

Your comments would be appreciated and can be provided on the Customer Response Form attached to the report.

This report can be obtained from the

U.S. Department of Energy

office of Scientific and Technical Information

P.0. Box 62

Oak Ridge, Tennessee 37831 


\section{DISCLAIMER}

This report was prepared as an account of work sponsored by an agency of the United States Government. Neither the United States Government nor any agency thereof, nor any of their employees, make any warranty, express or implied, or assumes any legal liability or responsibility for the accuracy, completeness, or usefulness of any information, apparatus, product, or process disclosed, or represents that its use would not infringe privately owned rights. Reference herein to any specific commercial product, process, or service by trade name, trademark, manufacturer, or otherwise does not necessarily constitute or imply its endorsement, recommendation, or favoring by the United States Government or any agency thereof. The views and opinions of authors expressed herein do not necessarily state or reflect those of the United States Government or any agency thereof. 


\section{DISCLAIMER}

Portions of this document may be illegible in electronic image products. Images are produced from the best available original document. 
U.S. DEPARTMENT OF ENERGY

OFFICE OF INSPECTOR GENERAL

Report Number: ER-B-95-06

Date of Issue: August 3, 1995
Eastern Regional Audit Office Oak Ridge, Tennessee 37830

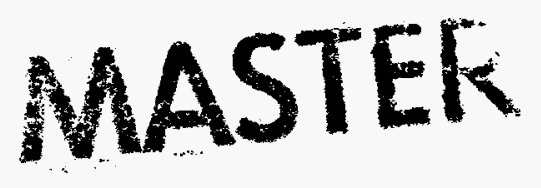




\section{AUDIT OF WORK FORCE RESTRUCTURING AT THE OAK RIDGE OPERATIONS OFFICE}

\section{TABLE OF CONTENTS}

\section{Page}

SUMMARY ................... I

PART I - APPROACH AND OVERVIEW............... 3

Introduction.................... 3

Scope and Methodology................ 3

Background.................... 4

Observations and Conclusions............ 6

PART II - FINDINGS AND RECOMMENDATIONS........... 8

1. Intended Benefits Not Achieved........ 8

2. Grant Funds Used for Lobbying......... 15

PART III - MANAGEMENT AND AUDITOR COMMENTS ......... 22 


\author{
U.S. DEPARTMENT OF ENERGY \\ OFFICE OF INSPECTOR GENERAL \\ OFFICE OF AUDIT SERVICES
}

\title{
REPORT ON AUDIT OF WORK FORCE RESTRUCTURING AT THE OAK RIDGE OPERATIONS OFFICE
}

Audit Report Number: ER-B-95-06

August 3,1995

\section{SUMMARY}

Lockheed Martin Energy Systems, Inc., (Energy Systems) operates the Oak Ridge National Laboratory, $\mathrm{Y}-12$ Plant, and $\mathrm{K}-25$ Site facilities in Oak Ridge, Tennessee, under a cost-plus-award-fee contract administered by the Oak Ridge Operations Office (Operations Office). The Operations Office formally announced that Energy Systems would restructure its work force to eliminate 865 positions in Fiscal Year (FY) 1993 and 1,400 positions in FY 1994. The audit objective was to determine whether Energy Systems and the Operations office effectively achieved the objectives of the Department of Energy's (Department) Defense Nuclear Facilities Work Force Restructuring Plan in FYs 1993 and 1994.

Energy Systems and the Operations office achieved the Department's restructuring objectives. The Department's downsizing goals were achieved at Oak Ridge without resorting to involuntary terminations. Voluntary separations and worker transfers negated the need for layoffs and associated worker assistance programs. Nevertheless, Energy systems established training programs and an outplacement center which, we found, provided little benefit to displaced workers or the Oak Ridge region. This condition occurred because the Department was not adequately involved in preparing the restructuring plans and did not curtail funding for training and outplacement programs when expected layoffs did not materialize. As a result, the Department unnecessarily spent about $\$ 8.2$ million in FYs 1993 and 1994, and plans to spend an additional $\$ 15.6$ million on comparable projects through FY 1997.

Federal law explicitly prohibits the use of appropriated funds for lobbying Congress and Federal officials. However, we found substantial lobbying activity under a grant the operations Office had awarded to an Oak Ridge advocacy group. In an attempt to sponsor local support for the restructuring program, the Department developed a grant statement of work that could be construed as permitting lobbying. The Operations office spent $\$ 219,000$ in FYs 1993 and 1994, and plans to spend an additional 
$\$ 231,000$ in FY 1995, much of which has been, or will be, used to lobby elected officials and Federal agencies.

Management nonconcurred with our findings and

recommendations. Management stated that expenditures for the training programs and outplacement center were necessary and reasonable to avoid involuntary layoffs. Management agreed that some of the grantee's activities may have been lobbying, but did not agree that the grant should be discontinued or restructured.

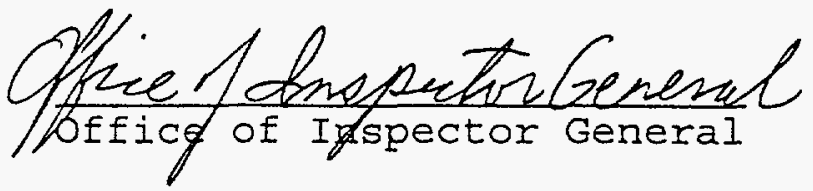

2 


\section{PART I \\ APPROACH AND OVERVIEW}

\section{INTRODUCTION}

The Oak Ridge Operations Office (Operations Office) announced plans to reduce the Lockheed Martin Energy Systems, Inc., (Energy Systems) work force by 865 positions in Fiscal Year (FY) 1993 and about 1,400 positions in FY 1994. The plans were coordinated with area stakeholders and announced 120 days in advance, in accordance with the requirements of the National Defense Authorization Act of FY 1993. The purpose of the audit was to evaluate the development and implementation of the Operations Office's work force restructuring plans. The audit objective was to determine whether Energy Systems and the Operations office effectively achieved the objectives of the Department of Energy's Defense Nuclear Facilities Work Force Restructuring Plan in FYs 1993 and 1994.

\section{SCOPE AND METHODOLOGY}

The audit was performed from June 23, 1994, through February 1, 1995, at the Department of Energy's (Department) Office of Worker and Community Transition in Washington, D.C., and at Energy Systems and the Operations Office in Oak Ridge, Tennessee. To achieve the audit objective, we relied extensively on computer processed data in Energy Systems' cost accounting and human resources information systems. We assessed the reliability of this data including relevant general and application controls and found them to be adequate. Based on these assessments, we concluded that the data were sufficiently reliable to be used in meeting the audit objective.

To accomplish the audit objective, we:

- Reviewed the requirements of Section 3161 of the National Defense Authorization Act of FY 1993 and the Department's implementing guidelines;

- Evaluated the development and implementation of the Operations Office's 1993 and 1994 work force restructuring plans;

- Analyzed restructuring costs incurred by Energy systems and the Operations Office in FYs 1993 and 1994; 
- Interviewed Energy Systems and Department employees involved in the development and implementation of the restructuring plans; and

- Evaluated the reasonableness of benefits provided to affected workers and the Oak Ridge community under the 1993 and 1994 restructuring plans.

The audit was performed in accordance with generally accepted government auditing standards for performance audits, and included tests of internal controls and compliance with laws and regulations necessary to satisfy the audit objectives. Accordingly, we assessed significant internal controls over work force restructuring activities. The assessment included reviews of Departmental policies, procedures, and responsibilities for work force restructuring actions. Because our review was limited, it would not necessarily have disclosed all internal control deficiencies that may have existed.

An exit conference was held on July 24, 1995, with the Oak Ridge Operations office and Energy Systems management. In addition, the audit results were discussed with the Director, office of Worker and Community Transition, on July 28, 1995.

\section{BACKGROUND}

Section 3161 of the National Defense Authorization Act of FY 1993 (Section 3161) requires the Department to develop a plan for restructuring the work force for a defense nuclear facility when significant layoffs are anticipated. Section 3161 also requires the Department to deliver the plan to Congress within 90 days after the public announcement of the anticipated layoffs.

In accordance with Section 3161, the Operations Office developed two work force restructuring plans. The first was approved by the Secretary in August 1993, and contemplated a reduction of 865 employees--765 at the $Y-12$ Plant and 100 at the Oak Ridge National Laboratory--at a proposed cost of $\$ 28.5$ million through FY 1995. The second plan was submitted to the Department's Task Force on worker and Community Transition for review in August 1994, and anticipated an additional reduction of 1,483 employees in FY 1994--at all Energy System components in Oak Ridge--at a proposed cost of $\$ 69.9$ million. As of February 1, 1995, the August 1994 plan had not yet been approved. 
The Operations office proposed the following benefits for Energy Systems employees and the Oak Ridge community under the 1993 and 1994 restructuring plans:

\section{Description}

Pension Benefit Enhancements

(1994 Only)

Supplemental Employee Training

Employee Retirement Incentives

Severance Pay and other

Separation Benefits

Displaced Worker Health Benefits

Local Community Impact Assistance

Outplacement Assistance

Educational Assistance After Layoff (1994 Only)

Relocation Assistance

Total

\begin{tabular}{rc}
1993 & 1994 \\
Plan & Plan \\
Amount & Amount \\
$(000)$ & $(000)$ \\
\hline
\end{tabular}

$\$$

0

$\$ 35,000$

15,394

5,992

8,359

26,624

1,937

210

2,061

210

450

600

250

1,182

97

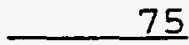

22

$\$ 28,526$

$\$ 69,937$

The amount shown above for the 1993 plan was the amount projected to be spent over 3 years (FYs 1993 through 1995) and the amount shown for the 1994 plan was the amount projected to be spent over 4 years (FYs 1994 through 1997), except for pension benefit enhancements of $\$ 35$ million. The pension benefit enhancements amount is the actuarial estimate of the cost of enhanced pension benefits to be paid over the lives of those who took the special retirement incentives in 1994. The pension plan had sufficient surplus funds to absorb the cost of the enhanced pension benefits. Funding for the 1994 plan will be provided partially from section 3161 funds and partially from other program funds. 
Layoffs proved unnecessary. Reductions were achieved primarily through voluntary retirements and separations. In addition, many employees transferred to other Energy Systems components in oak Ridge and others left through normal

attrition.

\section{OBSERVATIONS AND CONCLUSIONS}

Energy Systems and the Operations office are to be commended for achieving the Department's primary restructuring objective. With the passage of Section 3161, Congress attempted to ease the negative impacts restructuring the defense nuclear complex had on the lives of individual workers and local communities. Accordingly, the primary objective of the Department's restructuring program is to minimize layoffs when possible through retraining, early retirement, attrition, and other options. Energy Systems and the operations office effectively achieved the Department's downsizing goals at Oak Ridge without resorting to any layoffs. The restructuring was accomplished entirely through voluntary retirements and separations, normal attrition, and employee transfers.

While acknowledging the Department's accomplishments, we believe the Department could have more economically achieved the restructuring goals of Section 3161 at the Oak Ridge complex. Even though expected layoffs were avoided, Energy Systems initiated a Manufacturing Skills Campus, a High-Voltage Electrical Training Program, and an Administrative Technology Institute, and also created an outplacement center-none of which significantly benefited displaced workers or the Oak Ridge region. This condition occurred because the Department was not adequately involved in preparing the restructuring plans and did not curtail funding when expected layoffs did not materialize. As a result, the Department unnecessarily spent about $\$ 8.2$ million in FYs 1993 and 1994, and planned to spend an additional $\$ 15.6$ million on similar projects through FY 1997 . (See Part II, Finding 1.)

Also, we found appropriated funds were used for lobbying activities-which is prohibited by Federal law. The operations Office spent about $\$ 219,000$ in FYs 1993 and 1994 , and plans to spend an additional $\$ 231,000$ in FY 1995 under a grant made to an Oak Ridge advocacy group whose primary mission is to influence elected officials and Federal agencies for the oak Ridge community. Grant funds were partially used to lobby Federal and state officials. We believe the grant's statement of work and 
reimbursement provisions need to be modified to explicitly prohibit any funding of lobbying activities. (See Part II, Finding 2.)

We believe the efforts to reduce the burden of the Department's restructuring on longtime, loyal contractor employees and to minimize the economic impact on communities in and around the Department's facilities are laudable. We recognize, as well, that Department and contractor officials, working with community leaders, employee representatives, and other stakeholders, have made extraordinary efforts to make this program work. We are concerned, however, that should the program be viewed by those outside the Department as being managed imprudently or beyond the parameters established in the enabling legislation, continuation of such programs at Oak Ridge and at other facilities could be jeopardized. For this reason, we are hopeful that the Department views the results of our audit with care, despite the disagreement that has been expressed to date with many of our conclusions.

In our opinion, the findings in this report disclosed significant internal control weaknesses that the Department should consider when preparing the yearend assurance memorandum on internal controls. 


\section{PART II \\ FINDINGS AND RECOMMENDATIONS}

\section{Intended Benefits Not Achieved}

Section 3161 was intended to benefit individual workers who were displaced because of downsizing, and also to offset the adverse economic impact that downsizing would have on local communities. The training programs and the outplacement center established by Energy Systems using Section 3161 funds did not significantly benefit displaced workers or the Oak Ridge region, other than Energy Systems. This condition occurred because the Department was not adequately involved in preparing the restructuring plans and did not curtail funding when expected layoffs did not materialize. As a result, the Department unnecessarily spent about $\$ 8: 2$ million in FYs 1993 and 1994 , and planned to spend an additional $\$ 15.6$ million on similar projects through FY 1997.

\section{RECOMMENDATIONS} Office:

We recommend that the Manager, Oak Ridge Operations

1. Curtail funding for programs such as the Manufacturing Skills Campus that do not significantly help the intended beneficiaries of section 3161--displaced workers and the local community;

2. Develop procedures to ensure that work force restructuring plans are developed by Operations office employees consistent with Department-wide objectives; and

3. Monitor the implementation of work force restructuring plans to preclude unnecessary expenditures for programs that do not help displaced workers or the Oak Ridge community.

\section{MANAGEMENT REACTION}

The Chief Financial Officer, Oak Ridge Operations Office, nonconcurred with the finding and recommendations. Management stated that the restructuring programs helped the intended 
beneficiaries, and program costs were necessary and reasonable. Management stated that it curtailed funding for the programs when their activities no longer helped intended beneficiaries.

\section{DETAILS OF FINDING}

\section{INTENT OF SECTION 3161}

Section 3161 required the Department to establish a Defense Nuclear Facilities work Force Restructuring Plan to mitigate the impact of work force restructuring on displaced workers and affected communities. Section 3161 was intended to benefit individual workers who were displaced or separated (voluntarily or involuntarily) because of downsizing the nuclear facilities complex, and also. to offset the adverse economic impact downsizing would have on local communities.

\section{ACTUAL ACCOMPLISHMENTS}

Energy Systems and the Operations office achieved the Department's downsizing goals through voluntary retirements, transfers, and attrition. With respect to avoiding layoffs, the Department's accomplishments were fully successful. With respect to retraining, outplacement, and local economic development, however, the Department's accomplishments were limited. Three training programs and the outplacement center established by Energy Systems using Section 3161 funds did not significantly benefit displaced workers or the Oak Ridge region. Rather, the training programs merely upgraded skills of machinists, electricians, and secretaries in their current or related jobs, but did not prepare workers for new jobs. The outplacement center provided job-search assistance to all employees, but found jobs outside of Energy systems for only 10 employees, 3 of whom had been displaced by the restructuring.

\section{Training Program Benefits}

Energy systems established three training programs to enhance skills of employees in their current jobs:

- The Manufacturing Skilis Campus to upgrade machinist skills for Energy Systems employees and employees of other firms in the region. 
- The High-Voltage Electrical Training Program to update skills of in-house electricians.

- The Administrative Technology Institute to upgrade the skills of clerical workers in grammar, business math, and computer applications.

Each of these programs is discussed in more detail below.

\section{Manufacturing Skills Campus}

The Manufacturing skills Campus was not intended to prepare displaced employees for new jobs or occupations. Instead, the Campus had two missions-to upgrade the skills of Energy Systems' craft workers and to transfer manufacturing skilis from the Department to the private sector. The 1993 restructuring plan states the "Campus is both a worker retraining and community economic development initiative...to: transfer defense manufacturing technologies to private industry, use highly skilled electrical and machining personnel, use existing idle machining equipment, retrain the retained work force to prepare for new missions and program changes, and retain the manufacturing skills based in the Oak Ridge region." We believe the creation and operation of the Campus represents a significant expansion of Energy Systems into the field of education, which has traditionally been vested in local institutions.

Energy Systems used external and internal information to develop a curriculum for the Campus. Energy Systems solicited information on training needs in machining and environmental restoration from firms in Tennessee and neighboring states. Energy Systems also solicited information from firms within 150 miles of oak Ridge to identify open positions. The results of both solicitations, combined with an analysis of internal. training needs, were used to develop and provide courses in machine maintenance and operation, electronics, and quality inspection. Energy Systems had developed and conducted 18 courses as of July 1994. The campus trained 1,060 students in FY 1994, of which 83 percent were Energy Systems employees, and the remainder from private industry or students referred from local vocational schools. 
We believe the Campus does not satisfy a primary goal of Section 3161, which is to retrain displaced workers. Moreover, as discussed below, we believe the Campus, rather than providing local impact assistance, only broadened Energy Systems' operations into training and education.

The Campus is the creation of Energy Systems. Located at the Y-12 Plant site, the Campus is managed and staffed by Energy Systems personnel. The courses were developed and conducted by Energy Systems' machinists and workers.

The audit showed that it was unclear that a careful study of the relationship between the Campus and local existing educational institutions had been made. There was some concern, to be specific, that the campus could take business away from local educational institutions. A few courses overlapped or duplicated courses offered by a local community college. For example, Energy Systems developed a 40-hour introductory course on computer numerical control machine operation that duplicated a computer-aided machining course offered by the local community college.

Management stated that most of the courses offered by the skills campus were not available at local educational institutions, and that the local institutions welcomed the skills campus as providing more advanced studies for their own students.

\section{High-Voltage Electrical Training}

Energy Systems spent about $\$ 400,000$ to develop and conduct high-voltage electrical training courses through FY 1994. As with the skills Campus, Energy Systems' high-voltage training program did not meet the retraining goals of section 3161 . In fact, the high-voltage program was never intended to benefit displaced workers or provide local community assistance. Instead, the program was designed to enhance skills for work on high-voltage electrical systems and provide refresher training for general electricians.

A total of 104 electricians took one or more high voltage courses. Energy Systems advised us the courses were needed to backfill high voltage electricians lost during the 1993 voluntary reduction-in-force. However, we found only 39 electricians had left the plant, 28 of whom had transferred to other Energy Systems' components in Oak Ridge. 
These statistics do not, in our opinion, support the contention that this program benefited displaced workers. Nor could we locate any documentation to confirm that the program was of benefit to the local economy. On this basis, we concluded that the use of section 3161 funds for this purpose was questionable.

\section{Administrative Technology Institute}

Similar to the other training programs, the Administrative Technology Institute also did not meet the intent of section 3161. Rather than preparing workers for new jobs, this program upgraded skills of administrative personnel in grammar, business math, and computer applications. All courses were developed and taught by a local community college under a fixed-price

contract. A total of 61 administrative workers were enrolled in the program during our audit:. We found that no administrative workers participated in Energy Systems' voluntary reductions.

While we support the concept of self-improvement and employer-provided assistance for administrative workers, our analysis led us to conclude that section 3161 , as it was conceived, was not the proper vehicle for providing these kinds of enhanced job skills training exercises.

\section{Re-employment Assistance}

Energy Systems created an employee career center to provide job-search and counseling services for workers affected by the downsizing. However, instead of providing assistance to employees who were displaced by the restructuring, Energy Systems provided job-search assistance to employees who were not displaced.

Energy Systems spent $\$ 840,738$ in work force restructuring funds in FYs 1993 and 1994 to establish and operate an employee career center. The center was opened in April 1993 "to assist impacted workers in their job-search efforts during the 1993 downsizing." By August 1993., the center was staffed with four recruiters, two job-lead developers, six administrative support employees, an editor, a job derivative classifier, and a manager. The center remained open with a reduced staff immediately following the 1993 downsizing, and then expanded to 19 employees in April 1994. Work force restructuring funds paid for approximately one-half the cost of staffing the career center, and other program funds were used to pay the remainder. 
Career center services included the preparation of resumes and cover letters, job-skill assessments, educational and job-search counseling, job fairs, and computer library resources. The career center prepared 1,028 resumes and held 38 outplacement workshops in FY 1993. The center's activities resulted in 18 job offers to Energy Systems employees, of which 10 were accepted. However, only 3 of the 10 employees who accepted the new jobs were displaced by the work force restructuring plan.

Management stated that the career center expenditures were justified, even though there were no layoffs, because the center was used to reassign employees internally and perform job searches for employees taking early retirement. These activities, in our judgment, were precisely the activities that would normally be provided by Energy Systems' existing personnel division, without additional expenditures for a career center. As a consequence, the "value added" of the program for re-employment assistance was problematic. The concept of an active re-employment assistance program in a time when employees are being displaced is a well accepted practice in the private and public sectors. However, it is important, in our view, to evaluate the success of such programs, to ensure that they are as effective in operation as they are attractive on the drawing board.

\section{INADEQUATE DEPARTMENTAL INVOLVEMENT}

These conditions occurred because the Department was not adequately involved in preparing restructuring plans for the oak Ridge complex and did not adequately curtail funding when expected layoffs did not materialize.

Energy Systems developed the 1993 restructuring plan in accordance with preliminary draft guidance provided to the Operations office by Headquarters in March 1993. The preliminary guidance was revised in March 1994, placing responsibility for plan development directly on the operations offices. The operations offices were advised to seek assistance from contractors, but the plans were to be the Department's products. However, even after the guidelines were revised, the Operations office did not follow the guidelines and relied on Energy Systems to draft the 1994 plan, which was submitted to the Task Force on Worker and Community Transition in August 1994. 
Regardless of who prepared the plans, the responsible Department officials should have continually evaluated its impact, and we believe that such management would have disclosed that some of the proposed projects were inconsistent with Departmental objectives. The Operations office and the Task Force should have determined that retraining to enhance the skills of electricians and secretaries, as well intentioned as such activities may be, was outside the intent of section 3161 . Similarly, since Energy Systems achieved the Department's downsizing requirements without any involuntary terminations by using voluntary reduction-in-force incentives, the Department could have reduced spending for retraining and reemployment assistance.

\section{UNNECESSARY EXPENDITURE}

The Department spent about $\$ 8.2$ million and plans to spend an additional $\$ 15.6$ milizion on work force restructuring projects which were and are highly questionable. Energy systems spent Section 3161 funds totaling $\$ 7.4$ million in FYs 1993 and 1994 to develop and operate the Manufacturing Skilis Campus, the High-Voltage Electrical Training Program, and the Administrative Technology Institute. Also, Energy Systems spent Section 3161 funds totaling $\$ .8$ million in FYs 1993 and 1994 to develop and operate the employee career center. Energy systems plans to spend $\$ 5$ million on similar retraining projects and $\$ .6$ million on the career center in FYs 1995, 1996, and 1997. "In addition, Energy Systems plans to spend $\$ 10$ million on the Manufacturing Skilis Campus in FYs 1995, 1996, and 1997. 


\section{Grant Funds Used for Lobbying}

\section{FINDING}

Federal law prohibits the use of Government funds for lobbying elected officials or Federal agencies. However, the Department awarded a grant to a nonprofit advocacy group in oak Ridge, Tennessee, whose primary function was to influence elected officials and Federal agencies to bring new business and funds into the Oak Ridge community. The Department made the grant based on its interpretation of Congress' mandate to provide local impact assistance to communities affected by work force restructuring. As a result, the Department spent $\$ 219,000$ in Federal funds, and plans to spend an additional $\$ 231,000$, much of which will be used to lobby elected officials and Federal agencies.

\section{RECOMMENDATION}

We recommend that the Manager, Oak Ridge Operations office, direct the contracting officer to allow the grant to expire on September 30, 1995, and include a clear statement of work and appropriate reimbursement provisions in any follow-on grant to ensure that no Federal funds are used for lobbying activities.

\section{MANAGEMENT REACTION}

The Chief Financial officer, Oak Ridge Operations Office, nonconcurred with the finding and recommendation. Management stated that the statement of work does not permit or contemplate lobbying. The Department performed a 100-percent review of the Council's activities and determined that a portion of the Council's activities were potentially lobbying. The Department will seek repayment for costs related to questionable activities. In addition, the Department will issue additional suidance and direction to the council to clarify the lobbying issue. 
DETAILS OF FINDING

\section{FEDERAL RESTRICTIONS ON LOBBYING ACTIVITIES}

Federal law prohibits the use of Government funds for lobbying. Section 3152, title 31, U.S. Code states that no appropriated funds may be expended by the recipient of a Federal grant "... to pay any person for influencing or attempting to influence an officer or employee of any agency, a Member of Congress, an officer or employee of Congress, or an employee of a Member of Congress in connection with ... the awarding of any Federal contract, the making of any Federal grant, the making of any Federal loan, the entering into of any cooperative agreement; and the extension, continuation, renewal, amendment, or modification of any Federal contract, grant, loan, or cooperative agreement...."

\section{GRANT TO EAST TENNESSEE ECONOMIC COUNCIL}

The Department awarded a grant to the East Tennessee Economic Council (the Council), formerly the Roane-Anderson Economic Council, to assist the Operations office in developing the work force restructuring plan. The grant was for $\$ 150,000$ and covered the period May 21, 1993, through september 30, 1994. The Department modified the grant in April 1994, extending the period of performance through september 30,1995 , at an additional cost of $\$ 300,000$.

The Council, a division of the Oak Ridge Chamber of Commerce, is a non-profit organization of about 75 businesses and individuals. Before the Department's grant, the Council received most of its operating funds from member contributions. Corporate members paid an annual fee of $\$ 500$ and individual members paid an annual fee of $\$ 100$. The Council also received contributions from a few Oak Ridge firms, including Energy Systems.

The Council's formal-mission, action agenda, and actual activities confirm that influencing elected officials and other related lobbying were part of the Council's charter since inception. 
Council Mission and Action Agenda

The Council's stated mission is to ensure that the Government's presence remains a strong, growing, and viable part of the regional economy and to stimulate private sector economic growth in East Tennessee. The Council's action agendas for Calendar Years (CY) 1993 and 1994 stated "The Council functions to represent the interests of our members through the legislative process with elected officials and Federal Agencies." The Council's CY 1994 action agenda included the following specific projects:

1. Attract sufficient investment from the private sector and Federal agencies to preserve the Oak Ridge Centers for Manufacturing Technology. Base funding is required from the Department of Energy for FY 1995 and the next several years in order to help.

2. Ensure that construction Iine-item funding of \$40 million remains in the FY 1995 budget for the Advanced Neutron Source facility in Oak Ridge. Total construction funding over a 9-year period will require about $\$ 1.9$ billion and will employ several hundred people during construction and operation.

3. Ensure that the Department of Energy continues full funding of the Oak Ridge Centers for Environmental Technology and Waste Management and seek national designation for both centers. Also, encourage the Secretary of Energy to formally designate Oak Ridge as the site of the proposed National Environmental Management Academy.

4. Seek formal designation for the Oak Ridge Transportation Technology Center, and seek additional funding to expand transportation technology efforts.

5. Promote the appropriation of about $\$ 100$ million to consolidate biological research in a state-of-the-art facility at the Oak Ridge National Laboratory. About 70 percent of this funding will be for new research equipment.

6. Secure funding commitments from the Department of Energy from existing FY 1994 funds and seek additional funding in FYs 1995 and 1996 for East 
Tennessee 2000 projects. Additional funding for certain projects must come from the Economic Development Administration.

7. Encourage members of the Tennessee Congressional Delegation to be aware of the economic impact of international trade policies on Tennessee businesses and the economic contributions of these businesses to the region and state.

8. Ensure that Federally-elected representatives from Tennessee are aware of the Oak Ridge National Laboratory's Work For others Program and the Tennessee Valley Authority's Technology Partnering Program and the economic importance of these programs to the region.

9. Support the Tennessee Proposal for a National Information Infrastructure pilot demonstration grant. Use the Technology 2020 project as a major example of Tennessee's commitment to the National Information Infrastructure.

10. Make the Tennessee Congressional Delegation aware of the economic benefit of the National Aeronautics and Space Administration Space Station to Tennessee and its importance to the scientific community. For the most part, the Tennessee Congressional. Delegation has been opposed to this project because of the large proposed budget.

11. Ensure that East Tennessee regional companies have fair access to funds available from the Department of Commerce for advanced manufacturing technology projects.

Based on the Council's agenda described above, including its stated attempts to influence the appropriation process, the mission of the Council was oriented toward obtaining Federal funds for selected Oak Ridge projects and facilities through its activities within the Congress and Federal agencies.

\section{Council Lobbying Activities}

Council activity reports show that lobbying of Congress and Federal agencies actually occurred. Summaries of the Council's work force restructuring activities from May 1993 through July 1994 revealed that the Council's President and 
Executive Director held many meetings with elected officials and Federal agencies to lobby for new business and funds for the Oak Ridge community. These meetings involved Members of Congress, employees of Members of Congress, high-ranking Federal officials, state legislators, and the state Public service Commissioner and his staff. Several examples are summarized below.

1. The Council's Executive Director accompanied the Senior Vice President of an Oak Ridge firm on a trip to Washington, D.C., to visit a U.S. Senator. The Oak Ridge firm had a Government contract to revamp computer systems, and was seeking a similar contract with the Internal Revenue service. The Council assisted the firm in its attempts to obtain the new contract in order to bring 300 new jobs to Oak Ridge.

2. The Council's President and Executive Director traveled to Washington, D.C., to brief the Tennessee Congressional Delegation on the Council's activities and to "lay the ground work for their assistance in helping identify sources of funds in other agencies that can be utilized in the workforce Restructuring Plan."

3. The Council cohosted a luncheon for the Chairman of a Senate Committee, the Lieutenant Governor of the State of Tennessee, and the Oak Ridge Operations Office Manager at the Oak Ridge Chamber of Commerce. The Council President gave a presentation on the Technology 2020 Resource Center during the luncheon.

4. The Council arranged for regional stakeholders to travel to Washington, D.C., to meet with Members of Congress and the Chairman of the Department's Task Force on Worker and Community Transition regarding funds for a proposed project. The Council's activity report stated "Many stakeholders remain puzzled and angry that the stakeholder-driven proposal has not been funded." The Council members and stakeholders met with Members of Congress, and were accompanied by congressional employees in their subsequent meeting with the Task Force Chairman. The requested funds were subsequently provided for the project. 
5. A Council member traveled to Nashville, Tennessee, and met with the Public Service Commissioner and his staff to seek Public Service Commission funding for construction of the Technology 2020 project in Oak Ridge.

\section{INTERPRETATION OF CONGRESSIONAL INTENT}

Section 3161 required the Department to provide local impact assistance to communities that were affected by restructuring. Section 3161 also required the Department to coordinate the provisions of its local impact assistance with programs carried out by the Departments of Labor and Commerce. Congress did not define local impact assistance and did not specify provisions that should be included in the Department's impact assistance programs.

The Department interpreted "local impact assistance" broadly and designed a grant statement of work that had few Iimitations. Under grant terms, the council was to (1) serve as a liaison between regional stakeholders and Energy Systems and the Department to develop local impact assistance plans and programs; (2) serve as the lead coordinator for regional stakeholders with local, state, and Federal agencies; (3) analyze job opportunities in the region for displaced workers, identify and apply for Government assistance programs, and coordinate to ensure timely delivery of available services; (4) identify the need for'longer-term initiatives which can help diversify and strengthen the local economy; (5) create new job opportunities by attracting new companies to the region, helping existing companies expand, and starting new technology-oriented companies; and (6) help integrate regional efforts with future Department plans and policies to ensure close public-private sector cooperation toward regional goals and objectives.

The local impact assistance provisions of section 3161 were not intended to provide Federal funds for lobbying elected officials or Federal agencies for local projects. The underlying purpose of section 3161 was to mitigate the impact of the Department's work force restructuring on displaced employees and affected communities. Section 3161 stated that the Secretary of Energy would consult with the Secretary of Labor, appropriate representatives of departments and agencies of state and local governments, and appropriate representatives of community groups in communities affected by the restructuring plan to develop local impact assistance plans. Also, section 3161 encouraged community involvement in developing initiatives that would offset the impacts of downsizing. 
Moreover, Department regulations require grant recipients to certify that no funds will be used by the recipient to lobby elected officials or Federal agencies. The Council President certified to that effect in May 1993.

\section{COST OF LOBBYING}

Under the Department's grant to the Council, the Department spent $\$ 219,000$ in FYs 1993 and 1994 , and plans to spend an additional $\$ 231,000$ in FY 1995. Based on the data presented in its own agenda and activity reports to the Department, most of these funds were used for lobbying elected officials and Federal agencies on behalf of the Oak Ridge Chamber of Commerce.

The grant provided reimbursement for 75 percent of the compensation paid to the Council's Executive Director and 50 percent of the compensation paid to the Council's President, who was also President of the Oak Ridge Chamber of Commerce. Additionally, the grant provided reimbursement of travel expenses for the Executive Director, President, and other Council employees who assisted the Department in planning the work force restructuring. Furthermore, the grant provided reimbursement for materials, supplies, equipment, and consultants employed by the Council in planning for the work force restructuring.

We could not determine, with certainty, the portion of time or money spent by the council in lobbying activities. Also, we could not determine the portion of time spent by the Council in lobbying activities that were actually reimbursed by the Department. Nevertheless, many of the activities of the Council suited the commonly understood definition of lobbying. Therefore, in our opinion, the Department should allow the grant to expire on september 30, 1995, and include a clear statement of work and appropriate reimbursement provisions in any follow-on grant to ensure that no funds are used for lobbying activities. 


\section{PART III \\ MANAGEMENT AND AUDITOR COMMENTS}

The Chief Financial Officer, Oak Ridge Operations Office, nonconcurred with our findings and recommendations. Management stated that expenditures for the training programs and outplacement center were necessary and reasonable to avoid involuntary layoffs. The comprehensive planning and cooperative efforts by the Department, contractors, and employee representatives directly contributed to the success of the restructuring program. Funding for most of the programs was curtailed when the programs no longer helped intended beneficiaries. With respect to lobbying, management stated that some of the grantee's activities might have been lobbying, but did not agree to let the grant expire or to clarify the grant's statement of work and reimbursement provisions. Instead, management will direct the grantee to avoid certain questionable activities and seek recovery from the grantee for previous questionable activities. Management's comments on the recommendations and our responses follow.

Finding 1 - Management Control

Recommendation 1 . We recommend that the Manager, Oak Ridge Operations office, curtail funding for programs such as the Manufacturing Skills Campus that do not significantly help the intended beneficiaries of Section 3161--displaced workers and the local community.

Management Comments. Management nonconcurred, stating that the training and career center programs helped displaced workers and the local community. Management stated that the audit report uses the term "displaced workers" to mean only workers who are involuntarily laid off, and does not consider workers who are reassigned or voluntarily separate or retire. Management's explanation for each of the programs discussed in the report are summarized below.

Manufacturing Skills Campus: Management contended the Campus helped mitigate the impact of the restructuring for displaced workers and the local community by (1) avoiding layoffs of machinists, maintenance craft workers, and technical support workers by employing them as instructors at the Campus, and (2) improving worker skills in the private sector through courses provided by the Campus. 
Management also advised it is considering a proposal to expand the role of the Campus to train workers affected by the restructuring of other Departmental facilities during the next 2 years. Department management at the highest levels have supported funding for the skills campus from its inception.

High-Voltage Electrical Training: Management contended that this program assisted displaced electrical workers and enhanced the competency of all electrical workers. Without the program, three Energy Systems electricians would have been separated. Although management did not agree with the finding, Section 3161 funding was discontinued for the program during the audit.

Administrative Technology Institute: Management contended that the Institute helped clerical employees who were vulnerable to displacement and upgraded clerical workers' skills, thereby increasing their flexibility to effectively perform work within Energy Systems. Although management did not agree with the finding, the program was discontinued during the audit.

Employee Career Center: Management contended that the Employee Career Center helped avoid employee separations and was used to reassign employees affected by the restructuring to other Energy Systems components in Oak Ridge that were not affected. Internal plaçement was the Employee Career Center's first priority. Mánagement credits reassignments within Energy systems as minimizing disruption and saving many jobs.

Auditor Comments. Although management disagreed with the finding, the Department curtailed spending for High-Voltage Electrical Training, the Administrative Technology Institute, and the Employee Career Center during the audit. Management, in denying that the audit findings were responsible for this action, stated that spending was curtailed because the programs no longer benefited displaced workers.

The Department should take parallel actions with regard to the Manufacturing Skills Campus. Although the Campus provides teaching jobs for several Energy Systems employees, program costs appear to be out of proportion to the reported benefits to displaced workers and the local community. The Campus' proposal to train workers affected by restructuring at other Departmental sites could result in yet another costly expansion of the Department's mission in Oak Ridge. It seems reasonable that the affected workers at other locations could attend similar courses 
at local training facilities without incurring large travel and per diem costs. We believe that any proposal to expand activities at the skills Campus should be subject to scrutiny and analysis by the Department to ensure that the benefits exceed the costs.

We also disagree with management's statement that the term "displaced workers" as used in this report means only workers who are involuntarily laid off. The term also applies to workers who are reassigned or who voluntarily separate or retire due to the restructuring. The training programs were beneficial to the extent they provided teaching positions for Energy Systems employees. Also, the career center was beneficial to the extent it was used to reassign employees internally. However, we believe spending for these programs exceeded the benefits achieved for displaced workers and the local community.

Recommendation 2. We recommend that the Manager, Oak Ridge Operations Office, develop procedures to ensure that work force restructuring plans are developed by Operations Office employees consistent with Department-wide objectives.

Management Comments. Management nonconcurred, stating that the Operations office actively managed the restructuring. Departmental guidelines recognize that contractors are the principal source of knowledge and information on many restructuring issues and allow field activities to seek contractors' assistance in developing plans. Although Energy Systems was involved, the Department made the policy decisions regarding plan development. The Operations office will ensure that future plans are developed consistent with Departmental guidelines; however, no local procedures are necessary.

Auditor Comments. We believe the Department would not have created the programs discussed in this report if the Department had developed the plan based on information it gathered from all local stakeholders instead of proposals prepared by Energy Systems. The Operations Office should develop procedures to ensure that future restructuring programs are developed by the Department in full consideration of all stakeholders' needs.

Recommendation 3. We recommend that the Manager, Oak Ridge Operations office, monitor the implementation of work force restructuring plans to preclude unnecessary expenditures for programs that do not help displaced workers or the Oak Ridge community. 
Management Comments. Management nonconcurred, stating that the Operations Office had actively monitored the implementation of the restructuring plans, and unnecessary expenditures did not result as discussed in response to recommendation 1 .

Auditor Comments. Management did curtail section 3161 spending for several restructuring programs during our audit. However, we believe the Department could have avoided a significant portion of earlier spending for these programs if the Operations office had monitored the programs more closely.

\section{Finding 2 - Grant Funds Used for Lobbying}

Recommendation. We recommend that the Manager, Oak Ridge Operations Office, direct the contracting officer to allow the grant to expire on september 30, 1995, and include a clear statement of work and appropriate reimbursement provisions in any follow-on grant to ensure that no Federal funds are used for lobbying activities.

Management Comments. Management disagreed with the finding and recommendation. Management stated that the grant's statement of work did not permit or contemplate lobbying. However, management concluded that the statement of work did "leave the door open for potential lobbying to occur." Therefore, management will issue guidance to the grantee to clarify the issue.

Management performed a 100-percent review of the Council's activities and identified instances of potential lobbying. Management's comments regarding specific examples in the report (pages 17 and 18) follow:

- Management stated that the first example may have been lobbying. However, the trip may not have constituted lobbying by the council, since the council did not have a financial interest in the award and did not discuss any award or solicitation affecting the council. Nevertheless, managiement questioned $\$ 253$ of incidental expenses and $\$ 250$ of the Executive Director's salary.

- Management did not believe the second example was lobbying because the trip was requested by the Tennessee Congressional Delegation. In adition, the mere discussion with legislative personnel regarding future funding sources does not constitute lobbying activities. Federal regulations state that the 
prohibition against lobbying does not apply if the activities are not directly related to a covered Federal action. Since the council did not discuss any specitic Federal proposals, the discussion could not be directly related to any one specific covered Federal action.

- Management determined that the third example may have been lobbying. Although the luncheon presentation was requested by legislative officials, the formal application for a grant on Technology 2020 was in Departmental Headquarters for review and approval, and the Council may have used this meeting to influence the Department's approval of the grant application. Management will question 4 hours of Council members' salaries.

- Management did not agree that the fourth example was lobbying. The meeting was requested by the Department, and Federal regulations state that the providing of information specifically requested by an agency is allowable at any time. However, management did question the prudence of the meeting with the Tennessee Congressional Delegation and obtaining their support for the meeting with the Department. The grantee will be cautioned that if this occurs again, the costs will be questioned.

- Management did not agree that the fifth example was lobbying because the visit was made to influence state rather than Federal legislators. Management stated that Federal lobbying regulations only apply to lobbying activities related to Federal legislators or Federal agencies, and not to state activities.

Auditor comments. We believe the corrective action proposed by management will not prevent the Department's funding of lobbying activities. The Department will continue to fund lobbying activities as long as it funds portions of council members' salaries because lobbying is the primary function of the Council.

The Department should not have awarded the grant to the Council. A basic principle of appropriations law is that a Government agency should not do indirectly what it is prohibited from doing directly. Thus, since the Department is prohibited from spending appropriated funds to lobby elected officials for its programs or activities, it should not circumvent this restriction by passing funds for lobbying through a grantee. 
Therefore, the Department should either let its grant with the Council expire on september 30, 1995, or revise the terms of the grant to ensure that employees involved in local impact assistance planning are not also involved in lobbying for the Department's programs and plans.

We also disagree with management's response to the second, fourth, and fifth examples of lobbying activities in the report. With respect to the second example, we believe that the Council's attempts to obtain assistance in identifying fund sources applies to all Federal action items on its agenda. Thus, discussions regarding the Council's entire agenda are subject to prohibition against lobbying activities directly related to a Federal action. We do not believe the prohibition should be limited to discussions of "one specific covered Federal action."

With respect to the fourth example, we agree that the Task Force Chairman requested the meeting with the Council, but he did not request the Council to bring Congressional employees and angry stakeholders to the meeting to influence his decision to approve or disapprove the Council's proposal. We believe the Council's attempt to obtain Congressional influence in the Department's decision-making process was lobbying by any definition of the term.

With respect to the fifth example, we agree that the Federal prohibition against lobbying does not address lobbying of state officials. Even though the law is silent in this regard, we believe Federal funds should not be used to lobby State officials for the same reasons it should not be used to lobby Federal officials. 
IG Report No. ER-B-95-06

\section{CUSTOMER RESPONSE FORM}

The Office of Inspector General has a continuing interest in improving the usefulness of its products. We wish to make our reports as responsive as possible to our customers' requirements, and therefore ask that you consider sharing your thoughts with us On the back of this form, you may suggest improvements to enhance the effectiveness of future reports. Please include answers to the following questions if they are applicable to you:

1. What additional background information about the selection, scheduling, scope, or procedures of the audit or inspection would have been helpful to the reader in understanding this report?

2. What additional information related to findings and recommendations could have been included in this report to assist management in implementing corrective actions?

3. What format, stylistic, or organizational changes might have made this report's overall message more clear to the reader?

4. What additional actions could the Office of Inspector General have taken on the issues discussed in this report which would have been helpful?

Please include your name and telephone number so that we may contact you should we have any questions about your comments.

Name

Date

Telephone

Organization

When you have completed this form, you may telefax it to the Office of Inspector General at (202) 586-0948, or you may mail it to:

Office of Inspector General (IG-I)

Department of Energy

Washington, D.C. 20585

ATTN : Customer Relations

If you wish to discuss this report or your comments with a staff member of the office of Inspector General, please contact Wilma slaughter (202) 586-1924. 